Case 1 was kindly referred by Mr. C. R. Berkin of the Westwood Hospital, Beverley; Case 2 by Professor S. J. Hartfall ; and Case 3 by Dr. E. C. Allibone of the Leeds General Infirmary. I am grateful to Sister Thwaite, S/N Whan, and the dietetic, nursing, and technical staff of the metabolic unit for continual co-operation, without which studies such as these would be impossible. Miss V. Grayson and Mr. D. Newton carried out all the calcium and phosphorus measurements. Dr. F. W. Heaton and Dr. A. Hodgkinson of the urological research laboratories kindly carried out the magnesium measurements and the renal tubular reabsorption of phosphate respectively.

\section{REFERENCES}

Albright, F., Butler, A. M., and Bloomberg, E. (1937). Amer. F. Dis. Child., 54, 529.

Arneil, G. C., and Crosbie, J. C. (1963). Lancet, 2, 423.

Benson, P. F., Stroud, C. E., Mitchell, N. J., and Nicolaides, A. (1963). Brit. med. f., 1, 1054.

Dent, C. E. (1952). F. Bone ft Surg., 34B, 266.

- and Harris, H. (1956). Ibid., 38B, 204.
Dunnigan, M. G., Paton, J. P. J., Haase, S., McNicol, G. W., Gardner, M. D., and Smith, C. M. (1962). Scot. med. f., 7, 159.

Fales, F. W. (1953). F. biol. Chem., 204, 577.

Fanconi, G., and Giradet, P. (1952). Helv. paediat. Acta, 7, 14.

Fiske, C. H., and SubbaRow, Y. (1925). F. biol. Chem., 66, 375.

Frame, B., and Smith, R. W. (1958). Amer. F. Med., 25, 771.

- Fleming, J. L., and Manson, G. (1963). Amer. f. Dis. Child., 106, 147.

Fraser, D., Jaco, N. T., Yendt, E. R., Munn, J. D., and Liu, E. (1957). Ibid., 93, 84.

Kenny, A. D., and Toverud, S. U. (1954). Analyt. Chem., 26, 1059.

Pedersen, H. E., and McCarroll, H. R. (1951). F. Bone ft Surg., 33A, 203.

Rose, G. A. (1964a). Gut, 5, 274.

- (1964b). Clin. Radiol., 15, 75.

- (1964c). Postgrad. med. 7., 40, 158.

Saville, P. D., Nassim, J. R., Stevenson, F. H., Mulligan, L., and Carey, M. (1955). Clin. Sci., 14, 489.

Steendijk, R. (1961\%). Arch. Dis. Childh., 36, 321.

Stewart, W. K., Mitchell, R. G., Morgan, H. G., Lowe, K. G., and Thomson, J. (1964). Lancet, 1, 679.

Wilson, D. R., and Yendt, E. R. (1963). Amer. F. Med., 35, 487.

Winters, R. W., Graham, J. B., Williams, T. F., McFalls, V. W., and Burnett, C. H. (1958). Medicine (Baltimore), 37, 97.

\title{
Enlargement of Parotid Gland Due to Sarcoidosis
}

\author{
G. GREENBERG,* M.B., B.SC. ; R. ANDERSON, $\dagger$ M.B. ; P. SHARPSTONE, $\ddagger$ M.B., M.R.C.P. ; \\ D. GERAINT JAMES, M.A., M.D., F.R.C.P.
}

Brit. med. F., 1964, 2, 861-862

Of 388 patients with histologically confirmed generalized sarcoidosis, $23(6 \%)$ were observed to have enlargement of the parotid gland. This report analyses the associated clinical, radiological, histological, and immunological features so that one of the many causes of enlargement of the parotid gland may be more clearly delineated.

\section{Patients and Methods}

All patients were studied in a special sarcoidosis clinic by methods previously described (Anderson, James, Peters, and Thomson, 1962). They all showed clinical and/or radiological features of sarcoidosis, together with histological evidence of sarcoid tissue. Tissue for examination included biopsies of parotid gland, lymph nodes, skin, and liver. The Kveim test was carried out in 13 cases.

\section{Results}

The enlargement was bilateral in $19(83 \%)$ cases, right-sided in three, and left-sided in one.

Presenting Features.-Sixteen patients (70\%) presented with swollen glands or dryness of the mouth, or both; 10 of these also mentioned pain or discomfort of the eyes at their first visit. The only initial complaint of three patients was of sore or dry eyes.

Age and Sex Incidence.-There was no significant difference between the incidence of enlargement of the parotid gland in the sexes; 13 of the 23 patients were women, a trend which

- Research Assistant, Royal Northern Hospital, London. t Late Research Assistant, Reyal Northern Hospital, London.

₹ Medical Registrar, Royal Northern Hospital, London.

S Physician, Royal Northern Hospital, London. follows the overall distribution of sarcoidosis in the clinic. In 16 the onset was in the third or fourth decade of life, a pattern also similar to that seen in sarcoidosis as a whole. It occurred in men more commonly in the third decade compared with a mean age of onset of 44 years in women (Table I).

Other Tissues Involved.-There was widespread involvement of tissues other than the parotid glands (Table II). In 18 cases there were intrathoracic radiological changes; the early stage of bilateral hilar lymphadenopathy was seen in seven, enlargement of hilar glands was associated with pulmonary mottling in nine, and in two the still older stage of diffuse pulmonary infiltration without hilar adenopathy had been reached ; subsequent complete resolution of the chest radiographic abnormalities was observed in nine (50\%) cases.

TABLE I.-Age and Sex of 23 Patients with Enlargement of Parotid

\begin{tabular}{|c|c|c|c|c|c|c|}
\hline \multirow{2}{*}{\multicolumn{5}{|c|}{ Age at Onset }} & \multicolumn{2}{|c|}{ No. of Patients } \\
\hline & & & & & \multirow{2}{*}{$\begin{array}{c}\text { Male } \\
1 \\
5 \\
4 \\
0 \\
0\end{array}$} & \multirow{2}{*}{$\begin{array}{c}\text { Female } \\
0 \\
3 \\
4 \\
3 \\
3\end{array}$} \\
\hline  & 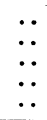 & 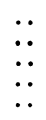 & $\begin{array}{l}\therefore \\
\therefore \\
\therefore\end{array}$ & 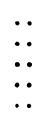 & & \\
\hline Total & $\ldots$ & $\ldots$ & $\ldots$ & $\ldots$ & 10 & 13 \\
\hline
\end{tabular}

Mean age at onset : males 28 years, females 44 years.

TABLE II.-Involvement of Other Tissues in 23 Patients with Enlargement of Parotid Gland

\begin{tabular}{|c|c|c|c|c|c|}
\hline \multicolumn{4}{|c|}{ System } & No. & $\%$ \\
\hline $\begin{array}{l}\text { Intrathoracic } \\
\text { Peripheral lymph } \\
\text { Skin } \\
\text { Spleen } \\
\text { Uveal tract } \\
\text { Lacrimal glands } \\
\text { Lacial nerve } \\
\text { Facia }\end{array}$ & $\begin{array}{l}\ddot{0} \\
\ddot{0} \\
\ddot{0}\end{array}$ &  & $\begin{array}{l}\ldots \\
\ldots \\
\cdots \\
\cdots \\
\cdots\end{array}$ & $\begin{array}{r}18 \\
15 \\
10 \\
9 \\
8 \\
4 \\
1\end{array}$ & $\begin{array}{r}78 \\
65 \\
43 \\
39 \\
35 \\
17 \\
4\end{array}$ \\
\hline
\end{tabular}


Peripheral lymph nodes were enlarged in 15 of the 23 cases, and in five of these the epitrochlear glands were palpable. The presence of associated iridocyclitis in eight patients constituted the syndrome of uveoparotitis, first described by Heerfordt (1909). In three of these patients ocular symptoms preceded enlargement of the parotid, a point which Heerfordt also emphasized. In two instances enlargement of the lacrimal glands with keratoconjunctivitis sicca mimicked the syndrome described by Sjögren (1933). Bell's palsy, right-sided and observed but once, is no more frequent than its overall incidence in sarcoidosis. This suggests that paresis of the facial nerve seen in sarcoidosis is not caused by pressure from an enlarged parotid gland, an observation previously made by Pennell (1951) and by Höök (1954).

Other Features.-Sarcoid tissue was obtained from several sites and the Kveim test was positive in $10(77 \%)$ of 13 cases (Table III). The Mantoux test was negative to an injection of 100 tuberculin units in $17(81 \%)$ of 21 patients. Both these features emphasize the activity of the disease in the group under discussion, especially since three patients were receiving systemic steroids when the tests were done. Raised or abnormal serum globulins were found in 10 out of 20 patients.

Fate of Enlargement of Parotid Gland.-In 10 instances the gland size returned to normal within six months. The patients were of either sex (four females), with a mean age of 32 years. Involvement of other systems was also benign and transient, so only two patients were given steroids. By way of contrast, parotid enlargement persisted over six months and up to three years in the remainder, eight of whom were women, with a mean age of 36 years in all. Because intrathoracic involvement was also chronic and persistent in this group, oral corticosteroids were prescribed for seven patients, but the results of such therapy were indifferent.

TABLE III.-Sites From Which Sarcoid Tissue was Obtained

\begin{tabular}{|c|c|c|c|c|c|c|}
\hline \multirow{2}{*}{\multicolumn{4}{|c|}{ Tissue }} & \multirow{2}{*}{$\begin{array}{c}\begin{array}{c}\text { No. } \\
\text { Biopsied }\end{array} \\
10\end{array}$} & \multicolumn{2}{|c|}{ Positive } \\
\hline & & & & & No. & $\%$ \\
\hline $\begin{array}{l}\text { Lymph node } \\
\text { Skin } \quad \ldots \\
\text { Liver } \quad . \\
\text { Parotid } \\
\text { Muscle } \\
\text { Kidney } \\
\text { Bone } \quad .\end{array}$ & $\begin{array}{l}\cdots \\
\cdots \\
\cdots \\
\cdots \\
\cdots\end{array}$ & $\begin{array}{l}\ldots \\
\cdots \\
\cdots \\
\cdots \\
\cdots\end{array}$ & $\begin{array}{l}. \\
\cdots \\
\cdots \\
\cdots \\
\cdots\end{array}$ & $\begin{array}{r}10 \\
9 \\
8 \\
4 \\
1 \\
1 \\
1\end{array}$ & $\begin{array}{r}10 \\
6 \\
3 \\
4 \\
1 \\
1 \\
1\end{array}$ & $\begin{array}{r}100 \\
67 \\
37 \\
100\end{array}$ \\
\hline
\end{tabular}

Kveim test was positive in $10(77 \%)$ of 13 cases.

\section{Discussion}

Involvement of the parotid gland due to sarcoidosis is but one incident in a disease affecting many systems. The most certain way of segregating sarcoid parotitis from the several causes of enlargement of the parotid gland is by seeking corollary evidence in other tissue systems and by obtaining histological proof of sarcoid tissue. In this series the widespread distribution of sarcoidosis is clearly shown (Table II and III) ; enlargement of spleen and lymph nodes, uveitis sometimes uncovered by slit-lamp examination of the eyes, and abnormalities in the chest radiograph being the most helpful for diagnosis. Histological confirmation was most conveniently obtained by biopsy of lymph node, skin, liver, or parotid, or by means of the Kveim test (Table III).

Sarcoidosis of the parotid gland may be acute, transient, and self-limiting or it may be chronic and persistent. In 10 patients the parotid glands returned to normal within six months ; in the remainder enlargement persisted. The patients with transient enlargement had a mean age of 32 years ; involvement of other systems was also transient. Steroids had no clear effect on the duration of glandular enlargement, chest radiographic changes, or of manifestations of sarcoidosis in other systems. This finding is in keeping with that of our entire series of patients, in whom steroids do not appear to have affected the prognosis of the disease, although they have influenced the natural history of one manifestation-sarcoid uveitis (James, Anderson, Langley, and Ainslie, 1964).

\section{Summary}

Of 388 patients with histologically confirmed generalized sarcoidosis $23(6 \%)$ had enlargement of the parotid gland. It was bilateral in 19, right-sided in three, and left-sided in one. The onset was most commonly in the third or fourth decade, affecting women in 13 instances. There was widespread involvement of other tissue systems, particularly lungs, lymph nodes and spleen, uveal tract, and lacrimal glands. Sarcoid tissue was obtained from several of these tissues. The Kveim test was positive in $77 \%$ and the Mantoux test negative in $81 \%$. The enlargement of the parotid gland subsided within six months in 10 patients, but persisted for varying periods up to three years in the remainder. Corticosteroids seemed unnecessary in the transient group and provided no clear-cut benefit in the chronic persistent type of enlargement of the parotid gland.

\section{REFERENCES}

Anderson, R., James, D. G., Peters, P. M., and Thomson, A. D. (1962). Lancet, 1, 1211 .

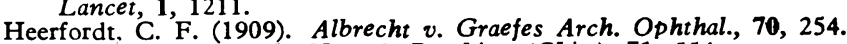

Heerfordt. C. F. (1909). Albrecht v. Graefes Arch. Ophthal.,
Höök, O. (1954). Arch. Neurol. Psychiat. (Chic.), 71, 554.

James, D. G., Anderson, R., Langley, D., and Ainslie, D. (1964). Brit. f. Ophthal., 48, 461.

Pennell, W. H. (1951). Arch. Neurol. Psychiat. (Chic.), 66, 728.

Siögren, H. (1933). Acta ophthal. (Kbh.), Suppl. No. 2. 